\title{
Influencing Factors on Customer Satisfaction and Retention in Online Transportation in Indonesia
}

\author{
Margaretha Pink Berlianto ${ }^{1}$, Rudy Pramono ${ }^{2}$, Yohana F. Cahya Palupi Meilani ${ }^{3}$ \\ \{margaretha.berlianto@uph.edu ${ }^{1}$, rudy.pramono@uph.edu ${ }^{2}$,yohana.meilani@uph.edu ${ }^{3}$ \} \\ Universitas Pelita Harapan , Jalan MH Thamrin Boulevard 1100 Lippo Karawaci Tangerang ${ }^{1,2,3}$
}

\begin{abstract}
This study aims to investigate the effects of sales promotion, online customer service, offline customer service, online dependencies, and corporate reputation on satisfaction and the effect of satisfaction on customer retention on online transportation in Indonesia. The population of this study was individuals who had used online transportation. The sampling technique used was purposive sampling. The data analysis method in this study is using PLS-SEM. The results of this study show that sales promotion, online customer service, offline customer service, and online dependencies have a positive effect on satisfaction and satisfaction have a positive effect on customer retention. This research has succeeded in contributing to the online transportation industry regarding the importance of sales promotion in creating customer sat isfaction, the importance for the manager to manage their online and offline customer service in order to satisfy their customers, how online dependencies can effect customer satisfaction and also how to create the customer retention.
\end{abstract}

Keywords: sales promotion, online dependency, reputation satisfaction, retention.

\section{Introduction}

Southeast Asian ride-hailing active users are 40 million in 2019, which increases five-time from 2015. In Indonesia, itself, the ride-hailing business achieved \$6 billion in 2019, highest among other countries in the Southeast Asian region, and predicted to achieve $\$ 18$ billion in 2025 (34\%) [1]. They offer convenience, value, and access to services and products that were previously difficult to obtain. This phenomenon caused intense competition between Indonesian and regional players, such as Gojek Indonesia and Grab Indonesia. To win this intense competition and sustainable, the online trans portation service company must have a competitive ad vantage compared to its competitors. Some source of competitive advantage is customer satisfaction and customer retention [2]. Maintaining customer retention is an essential thing for the company to do, due to its capability to implies a long-term relationship, could maintain a sustainable business, reduce transaction costs, maximize the economic and non-economic benefit, and with 5\% improvement in customer retention increased average customer value by $125 \%$ and can lead to a $75 \%$ increase in profitability [2]. There are two big players of online transportation in Indonesia, namely Gojek and Grab Indonesia. They competing closely each otherby offering a variety of services to create a sense of satisfaction with consumers because of customer retention is a critical element of every organization's success, retaining customers become heavy work in a very crowded market en vironment [3]. Grab, for example, is an online service ride-sharing owned by a Malaysian-based company 
and as the most often used brand in Indonesia compared to other transportation booking applications [4].

There are a lot of res earch on consumer retention in previous studies in medical touris $m$ [5], retail industries [6], [7], banking sector [8]. However, still limited study, particularly in investigate, Grab online transportation mode on customer satisfaction in Indonesia with data analyzing using the Smart PLS program. Then the res earch questions formulated are: (1) Do Sales promotion, Online customer service, Offline cus tomer service, Online dependency, and reputation have a positive effect on satisfaction? And Does satisfaction have a positive effect on customer retention? This study aims to investigate the effects of sales promotion, o nline cus tomer service, offline cus tomer service, online dependencies, and corporate reputation on satisfaction and the effect of satisfaction on customer retention on online transportation in Indonesia, especially Grab. This study is trying to contribute factors that online transportation should pay attention to, es pecially Grab-car in running their business so they could achieve consumer retention.

\section{Literature review}

\subsection{Satisfaction}

Service satisfaction is a result of perceived quality or value [9] nd has been considered as a fundamental determin ant of long-termcus tomer behavior [8]. Customer s atisfaction defined as a feeling or judgment of customers toward products or services after they have used them [10].

\subsection{Sales promotion}

Sales promotion is one of the most significant elements in marketing campaigns, and is usually used to encourage quicker purchases of particular products or services [6], and plays a significant role in an online shopping environment and advertis ing strategy [11]. According to [12], sales promotion is marketing activities that provide extra value for customers. Research results previously by [13], [14], [15] stated that sales promotion has a positive and significant effect on customer satisfaction. Thus:

H1: Sales promotion has a positive effect on satisfaction.

\subsection{Online Customer Service}

Customer service is particularly important for online and offline stores [16], [17], and has become an important source of competitive advantage of online stores [18]. The customer service of online stores is the provision of services to consumers before, during, and after a purchase. Customer service refers to a responsive, helpful, prompt service that res ponds to customer inquiries quickly [19]. The quality of online services als o becomes an indicator to determine cus tomer satisfaction, which found that online customer service has a positive effect on satisfaction [20]-[22]. Based on the description above, thus:

$\mathrm{H} 2$ : Online customer service has a positive effect on satisfaction

\subsection{Offline Customer Service}

Offline customer service in this study refers to the competencies of personnel or drivers of online trans portation in servicing their customers. Personneland customer interaction have a positive influence on satisfaction [23]. Previous research found that competencies of offline customer service have a positive effect on satisfaction [24]-[28]. Thus:

H3: Offline customer service has a positive effect on satisfaction 


\subsection{Online Dependency}

Dependency is now receiving more attention among researchers in the field of online marketing, such as in online social media [29] or in online services [30]. Consumers depend on service and its providers to fulfill their needs and goals. Habitual us age of online service is essential for service providers. Once customers are familiar with using online service, they will be more prone to depend on it [30]. Prior research has examined online behavior and platforms as resources that lead to dependency and have a positive effect on customer satisfaction [20], [30]. Thus:

H4: Online dependency has a positive effect on satisfaction

\subsection{Reputation}

Corporate reputation is unique, impossible to copy, and fundamental for corporate success [31]. A corporate reputation is "a collective assessment of a company's attractiveness to a specific group of stakeholders relative to a reference group of companies with which the company competes for resources" [32, p. 100]. According to [33], a company with a good brand reputation can form customer satisfaction. This statement supported by previous research found that corporatereputation has a positive effect on satisfaction [34], [35]. Thus: H5: Reputation has a positive effect on satisfaction.

\subsection{Retention}

Customer retention is one of the most crucial factors for a company due to the cost of acquiring new customers in volatile market environments is very high, and customers have become more profitable as they continue the business relationship with companies [8]. Customer retention as a customer's continuation of a business relationship with a firm [36]. Satisfied customers are believed to make more repeat purchases and to share their positive experiences with others [37], which in the end is turning become as customer retention. The more satisfied the customers are, the higher their retention is [8]. This statement in-line with previous research that showed that customer satisfaction has a positive effect on customer retention [8], [38]. Thus, the hypothesis developed as follows: H6: Satisfaction has a positive effect on customer retention.

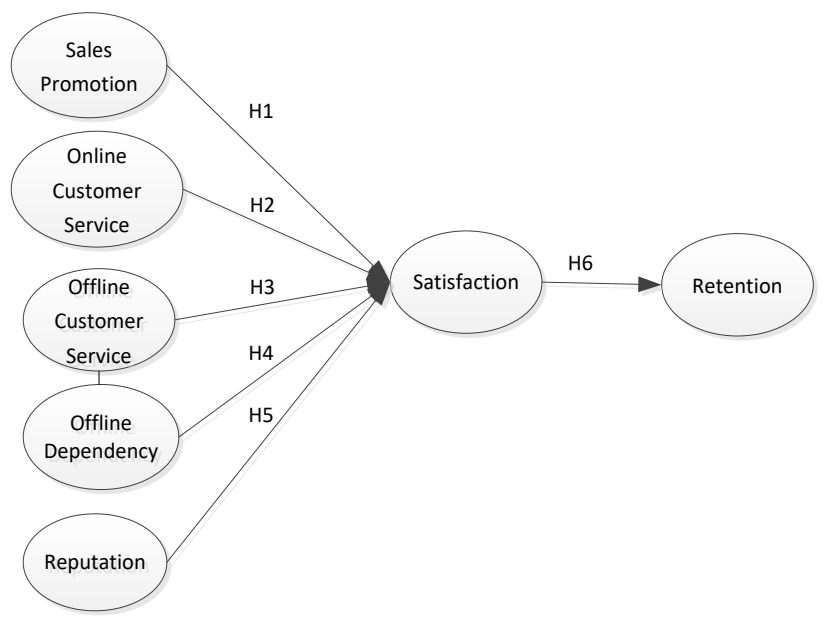

Fig. 1. Research Model 


\section{Methodology}

This study is quantitative research. The target population of this study is customers of Grab car Indonesia. Non-probability sampling design techniqueused was purposive sampling with three criteria: individuals who had ridden Grab car within the last three months and experienced Grab car more than three times. Thenumber of samples taken fromthis study was 200 respondents. All the indicators used in this study were taken from previous literature and adapted to the specific research problem. The sales promotion was measured using four indicators adopted from [6]. The online cus tomer service was meas ured using three indicators adopted from [19]. he offline customer service consists of four adopted from [24]. Online dependency was measured using three indicators adopted from [30]. Reputation was measured using threeindicators adopted from [39]. Satisfaction consists of three indicators adopted from [40]. Customer retention consists of four indicators adapted from [6] and [41]. The items were five point Likert type scale item. The data in this study were analyzed using PLS-SEM. According to [42], an indicator or variable is considers valid or reliable, if Composite Reliability value higher than 0.7 , Indicator loadings value higher than 0.6 , Convergent validity should have the Average Variance Extracted (AVE) value higher than 0.50 and Discriminant validity have the AVE of each latent construct should higher than the construct's highest squared correlation with any other latent construct. The preliminary study uses 30 respondents. All items' and variables are valid and reliable.

\section{Result and discussion}

In total, 192 valid questionnaires were received for the data analysis, with a response rate of $96 \%$. Table 1 presents that all indicators of all constructs have an outer loading value greater than 0.6, the Average Variance Extracted (AVE) value above 0.5 and the Composite Reliability value above 0.7 . So, it can be concluded that it has fulfilled the convergent validity requirements.

Table 1. Results of Measurement Model

\begin{tabular}{|c|c|c|c|}
\hline Measurement item & Loading & & Loading \\
\hline \multicolumn{2}{|c|}{ Sales promotion $(\mathrm{CR}=0.889 ; \mathrm{AVE}=0.668)$} & \multicolumn{2}{|c|}{ Reputation $(\mathrm{CR}=0.936 ; \mathrm{AVE}=0.830)$} \\
\hline SP1 & 0.843 & REP 1 & 0.897 \\
\hline $\mathrm{SP} 2$ & 0.686 & REP2 & 0.909 \\
\hline $\mathrm{SP} 3$ & 0.862 & REP3 & 0.926 \\
\hline \multicolumn{2}{|c|}{ Online $\mathbf{C S}(\mathrm{CR}=0.875 ; \mathrm{AVE}=0.701)$} & \multicolumn{2}{|c|}{ Satisfaction $(\mathrm{CR}=0.926 ; \mathrm{AVE}=0.806)$} \\
\hline PCS1 & 0.873 & SAT1 & 0.905 \\
\hline PCS1 & 0,838 & SAT2 & 0.900 \\
\hline PCS1 & 0,799 & SAT3 & 0.888 \\
\hline \multicolumn{2}{|c|}{ Offline CS $(\mathrm{CR}=0.869 ; \mathrm{AVE}=0.624)$} & \multicolumn{2}{|c|}{ Retention $(\mathrm{CR}=0.863 ; \mathrm{AVE}=0.614)$} \\
\hline $\mathrm{C} 1$ & 0.762 & CR1 & 0.798 \\
\hline $\mathrm{C} 2$ & 0.777 & CR1 & 0.860 \\
\hline $\mathrm{C} 3$ & 0.833 & CR1 & 0.659 \\
\hline $\mathrm{C} 4$ & 0.786 & CR1 & 0.803 \\
\hline \multicolumn{4}{|c|}{ Online dependeny $(\mathrm{CR}=0.905 ; \mathrm{AVE}=0.762)$} \\
\hline OD1 & 0.857 & & \\
\hline OD2 & 0.931 & & \\
\hline OD3 & 0.827 & & \\
\hline
\end{tabular}


As presented in Table 2, it is seen that all square roots of average variance extracted (AVE) are higher than the correlation coefficient between the constructs. It means that this study has adequate discriminant validity.

Table 2. Discriminant Validity of Constructs

\begin{tabular}{cccccccc}
\hline & OCS & ONCS & OD & REP & CR & SP & SAT \\
\hline OCS & $\mathbf{0 . 7 9 0}$ & & & & & & \\
ONCS & 0.442 & $\mathbf{0 . 8 3 7}$ & & & & & \\
OD & 0.445 & 0.495 & $\mathbf{0 . 8 7 3}$ & & & & \\
REP & 0.476 & 0.563 & 0.537 & $\mathbf{0 . 9 1 1}$ & & & \\
CR & 0.490 & 0.620 & 0.609 & 0.543 & $\mathbf{0 . 7 8 4}$ & & \\
SP & 0.346 & 0.322 & 0.417 & 0.299 & 0.418 & 0.818 & \\
SAT & 0.600 & 0.497 & 0.596 & 0.459 & $\mathbf{0 . 6 4 1}$ & 0.439 & $\mathbf{0 . 8 9 8}$ \\
\hline
\end{tabular}

To test the hypotheses, SEM approach were deployed. As display in Table 3, five hypotheses were supported, because of the $\mathrm{p}$-value $<0.05$ and $\mathrm{t}$-value $>1.65$, and one hypothes is were rejected.

Table 3. Path Coefficients and Hypotheses Testing

\begin{tabular}{llcccc}
\hline $\mathrm{H}$ & \multicolumn{1}{c}{ Path } & Coefficient & t-value & P value & Conclusion \\
\hline H1 & Sales promotion $\rightarrow$ satisfaction & 0.142 & 2.510 & 0.006 & Supported \\
H2 & Online customer service $\rightarrow$ satisfaction & 0.141 & 2.000 & 0.023 & Supported \\
H3 & Offline customer service $\rightarrow$ satisfaction & 0.349 & 5.538 & 0.000 & Supported \\
H4 & Online dependencies $\rightarrow$ satisfaction & 0.308 & 4.417 & 0.000 & Supported \\
H5 & Reputation $\rightarrow$ satisfaction & 0.006 & 0.072 & 0.471 & Not Supported \\
H6 & Satisfaction $\rightarrow$ retention & 0.641 & 17.733 & 0.000 & Supported \\
\hline
\end{tabular}

Sales promotion has a positive effect on satisfaction, meaning that when a company held a sales promotion, consumers feel satisfied with the offered. This study supports by previous research [13]-[15]. Online customer service has a positive effect on satisfaction, meaning Grab's online customer service that is available 24 hours and even acces sed through the web www.grab.com has a positive effect on customer satisfaction. This study supported by previous res earch [20]-[22]. Offline customer service has a positive effect on satis faction. It can be explained that when drivers give a good impression of the Grab service, then the customer will be satisfied. This study supported by previous research [24]-[28]. Online dependency has a positive effect on satisfaction, meaning consumers have a preference for choosing Grab as a transportation service compared to others. This result supported by previous studies [20], [30]. Reputation has not a positiveeffect on satisfaction, meaning that Grab's reputation in the eyes of consumers is already good soit has no effect on satisfaction. This result is not supported several studies by [34], [35]. Satis faction has a positive effect on customer retention meaning because their experienced, the consumers had positive feelings about Grab services, they were satis fied so that they repeated the trans action with Grab. This study supported by previous studies [8], [38]. 


\section{Conclusion}

This study succeeds in confirming that sales promotion, online customer service, offline customer service, and online dependency have a positive effect on satisfaction, and satisfaction has a positiveeffect on retention. Implications managerial for this study are the practitioners in these fields should pay attention to sales promotion, online customer service, offline customer service, and online dependency in order to increase customer satisfaction. Some of the strategies that manager can do regarding those factors are giving a sales discount to the consumer, particularly in happy hour when the transaction is less than usual, manage a responsive and helping online consumer services, training for the driver so they could deliver an excellent service and having a right competencies, updating their busines s model which customer could rely on this online trans portation, and manage customer satisfaction while providing the best service and be willing to correct deficiencies in services both online and offline. The limitation of this study is that this study only focuses on sales promotion techniques. Recommendations for future research are using this model in other online transportation or other services and doing the study in other cities.

\section{References}

[1]Google, Temasek, and Bain\&Company, "e-Conomy SEA 2019," 2019.

[2]W. A. Inkumsah, "Factors that impacted customer retention of banks: A study of recently acquired banks in the UPSA area of Madina, Accra ( Specifically Access Bank ).," J. Mark. Consum. Res. - An Open Access Int. J., vol. 1, pp. 88-103, 2013.

[3]G. Premkumar and J. Rajan, "Customer Retention in Mobile Telecom Service Market in India: Opportunities and Challenges," Ushus JBMgt, vol. 2, no. 12, pp. 17-29, 2013.

[4]Grab.com, "No Title," 2019. [Online]. Available: https://www.grab.com/id/brand-story/. [Accessed: 10-Oct-2019].

[5]H. Han and S. S. Hyun, "Customer retention in the medical tourism industry: Impact of quality, satisfaction, trust, and price reasonableness," Tour. Manag., vol. 46, no. October, pp. 20-29, 2015.

[6]J. R. Hanaysha, "Customer retention and the mediating role of perceived value in retail industry," World J. Entrep. Manag. Sustain. Dev., vol. 14, no. 1, pp. 2-24, 2018.

[7]G. Fullerton, "The moderating effect of normative commitment on the service quality-customer retention relationship," Eur. J. Mark., vol. 48, no. 3/4, pp. 657-673, 2014.

[8]M. A. Darzi and S. A. Bhat, "Personnel capability and customer satisfaction as predictors of customer retention in the banking sector: A mediated-moderation study," Int. J. Bank Mark., vol. 36, no. 4, pp. 663-679, 2018.

[9]C. K. Ayo, A. A. Oni, O. J. Adewoye, and I. O. Eweoya, "E-banking users' behaviour: e-service quality, attitude, and customer satisfaction," Int. J. Bank Mark., vol. 34, no. 3, pp. 347-367, 2016.

[10]K. Gupta and I. Bansal, "Development of an instrument to measure internet banking service quality in India," Res. World, vol. 3, no. 2 Part 2, p. 11, 2012.

[11]U. Akram, P. Hui, M. Kaleem Khan, Y. Tanveer, K. Mehmood, and W. Ahmad, "How website quality affects online impulse buying: Moderating effects of sales promotion and credit card use," Asia Pacific J. Mark. Logist., vol. 30, no. 1, pp. 235-256, 2018.

[12]G. E. Belch and M. A. Belch, Advertising and Promotion: An Integrated Marketing Communications Perspective, 10th ed. UK: McGraw- Hill Education, 2015.

[13]H. C. Huang, Y. T. Chang, C. Y. Yeh, and C. W. Liao, "Promote the price promotion the effects of price promotions on customer evaluations in coffee chain stores," Int. J. Contemp. Hosp. Manag., vol. 26, no. 7, pp. 1065-1082, 2014.

[14]J.-W. Park, Y.-J. Choi, and W.-C. Moon, "Investigating the effects of sales promotions on customer behavioral intentions at duty-free shops: An Incheon International Airport case study," J. Airl. Airpt. 
Manag., vol. 3, no. 1, pp. 18-30, 2013.

[15]S. Ubeja, "A Study of Sales Promotion Mix on Customer Satisfaction With Reference to Shopping Malls in Indore," Glob. J. Financ. Manag., vol. 6, no. 3, pp. 245-252, 2014.

[16]V. T. Dang and T. L. Pham, "An empirical investigation of consumer perceptions of online shopping in an emerging economy," Asia Pacific J. Mark. Logist., vol. 30, no. 4, pp. 952-971, 2018.

[17]T. Y. Eng, "E-customer service capability and value creation," Serv. Ind. J., vol. 28, no. 9, pp. $1293-$ 1306, 2008.

[18]P. Kotler and G. Armstrong, Principles of Marketing, 16th ed. London: Pearson Education Limited, 2016.

[19]M. Wolfinbarger and M. C. Gilly, "eTailQ: Dimensionalizing, measuring and predicting etail quality," J. Retail., vol. 79, no. 3, pp. 183-198, 2003.

[20]Q. Nguyen, T. M. Nisar, D. Knox, and G. P. Prabhakar, "Understanding customer satisfaction in the UK quick service restaurant industry: The influence of the tangible attributes of perceived service quality," Br. Food J., vol. 120, no. 6, pp. 1207-1222, 2018.

[21]E. Ahmadi Kashkoli, Sadegh Zarei, A. Daneshkohan, and S. Khodakarim, "Hospital responsiveness and its effect on overall patient satisfaction: A cross-sectional study in Ira," Int. J. Health Care Qual. Assur., vol. 30, no. 8, pp. 728-736, 2017.

[22]R. Kant and D. Jaiswal, "The impact of perceived service quality dimensions on customer satisfaction: An empirical study on public sector banks in India," Int. J. Bank Mark., vol. 35, no. 3, pp. 411-430, 2017.

[23]L. A. Crosby, K. R. Evans, and D. Cowles, "Relationship Quality in Services Selling: An Interpersonal Influence Perspective," J. Mark., vol. 54, no. July, pp. 68-81, 1990.

[24]X. Cheng, S. Fu, and G. J. de Vreede, "A mixed method investigation of sharing economy driven car-hailing services: Online and offline perspectives," Int. J. Inf. Manage., vol. 41, no. 10, pp. 57-64, 2018.

[25]J. Kayeser Fatima and M. Abdur Razzaque, "Roles of trust on rapport and satisfaction in services," Asia Pacific J. Mark. Logist., vol. 26, no. 4, pp. 566-578, 2014.

[26]C. Koo, N. Chung, and H. W. Kim, "Examining explorative and exploitative uses of smartphones: A user competence perspective," Inf. Technol. People, vol. 28, no. 1, pp. 133-162, 2015.

[27]C. Delcourt, D. D. Gremler, A. C. r. Van Riel, and M. Van Birgelen, "Effects of perceived employee emotional competence on customer satisfaction and loyalty: The mediating role of rapport," J. Serv. Manag., vol. 24, no. 1, pp. 5-24, 2013.

[28]M. Iqbal, N. Nisha, and M. Rashid, "Bank selection criteria and satisfaction of retail customers of Islamic banks in Bangladesh," Int. J. Bank Mark., vol. 36, no. 5, pp. 931-946, 2018.

[29]W.-H. S. T sai and L. R. Men, "Motivations and Antecedents of Consumer Engagement With Brand Pages on Social Networking Sites," J. Interact. Advert., vol. 13, no. 2, pp. 76-87, 2013.

[30]S. F. Chan, B. R. Barnes, and K. Fukukawa, "Consumer control, dependency and satisfaction with online service,” Asia Pacific J. Mark. Logist., vol. 28, no. 4, pp. 594-615, 2016.

[31]M. G. Casimiro Almeida and A. Coelho, "A causal relationship model linking corporate reputation and customer-based brand equity: A customer perspective," Acad. Rev. Latinoam. Adm., vol. 30, no. 2, pp. 249-268, 2017.

[32]C. J. Fombrun, The building blocks of corporate reputation: definitions, antecedents, consequences, Barnett, M. Oxford: Oxford University Press, 2012.

[33]R. Gul, "The Relationship between Reputation , Customer Satisfaction , Trust , and Loyalty," J. Public Adm. Gov., vol. 4, no. 3, pp. 368-387, 2014.

[34]C. A. M. Graca and C. Arnaldo, "The role of corporate reputation on co-operants behavior and organizational performance," J. Manag. Dev., vol. 35, no. 1, pp. 17-37, 2016.

[35]J. H. Liu, M. North, and C. Li, "Relationship building through reputation and tribalism on companies' Facebook pages: A uses and gratifications approach," Internet Res., vol. 27, no. 5, pp. 1149$1169,2017$.

[36]T. L. Keiningham, B. Cooil, L. Aksoy, T. W. Andreassen, and J. Weiner, "The value of different customer satisfaction and loyalty metrics in predicting customer retention, recommendation, and shareof-wallet," Manag. Serv. Qual. An Int. J., vol. 17, no. 4, pp. 361-384, 2007. 
[37]J. Tam, P. Sharma, and N. Kim, "Examining the role of attribution and intercultural competence in intercultural service encounters," J. Serv. Mark., vol. 28, no. 2, pp. 159-170, 2014.

[38]M. Mannan, N. Chowdhury, P. Sarker, and R. Amir, "Modeling customer satisfaction and revisit intention in Bangladeshi dining restaurants," J. Model. Manag., vol. 14, no. 4, pp. 922-947, 2019.

[39]D. Arli, P. van Esch, G. Northey, M. S. W. Lee, and R. Dimitriu, "Hypocrisy, skepticism, and reputation: the mediating role of corporate social responsibility," Mark. Intell. Plan., vol. 37, no. 6, pp. 706-720, 2019.

[40]C. Flavián, M. Guinalíu, and R. Gurrea, "The role played by perceived usability, satisfaction and consumer trust on website loyalty," Inf. Manag., vol. 43, no. 1, pp. 1-14, Jan. 2006.

[41]L. Zhao, Y. Lu, L. Zhang, and P. Y. K. Chau, "Assessing the effects of service quality and justice on customer satisfaction and the continuance intention of mobile value-added services: An empirical test of a multidimensional model," Decis. Support Syst., vol. 52, no. 3, pp. 645-656, 2012.

[42]J. F. Hair, C. M. Ringle, and M. Sarstedt, "PLS-SEM: Indeed a silver bullet," J. Mark. Theory Pract., vol. 19, no. 2, pp. 139-151, 2011. 